\title{
Vachellia farnesiana (L.) Wight \& Arn. Growing in Bangladesh Exerts In-vitro Antioxidant and In-vivo Analgesic and Anti-diarrheal Activities
}

\author{
Md. Sadman Hasib ${ }^{1}$, Md. Sazzadul Bari ${ }^{1}$, Akhteruzzaman Chowdhury ${ }^{2}$, \\ Md. Aslam Hossain ${ }^{1}$ and Mohammad A. Rashid ${ }^{1}$ \\ ${ }^{1}$ Department of Pharmaceutical Chemistry, Faculty of Pharmacy, University of Dhaka Dhaka-1000, Bangladesh \\ ${ }^{2}$ Government Bangla College, Mirpur-1, Dhaka, Bangladesh
}

(Received: June 16, 2020; Accepted: July 20, 2020; Published (web): July 25, 2020)

\begin{abstract}
The present study was conducted to evaluate the antioxidant, antidiarrheal and analgesic activities of Vachellia farnesiana (L.) Wight \& Arn. The methanol extract of $V$. farnesiana and its different fractionates were subjected to in-vitro assay for the determination of total phenolic content and antioxidative potential. The ethyl acetate soluble fraction (EASF) exhibited the highest free radical scavenging capacity ( $\mathrm{IC}_{50}$ value of $21.49 \pm 1.04 \mu \mathrm{g} / \mathrm{ml}$ ) as compared to that exhibited by the standard butylated hydroxyl toluene (BHT) ( $\mathrm{IC}_{50}$ value of $20.41 \pm 0.05 \mu \mathrm{g} / \mathrm{ml}$ ). Such prominent antioxidative potential was further reinforced by a phenolic content of $39.26 \pm 0.85 \mathrm{mg}$ of gallic acid equivalent per gram of extract. The plant extract, at the dose of $400 \mathrm{mg} / \mathrm{kg}$ body weight, reduced castor oil-induced diarrhea in mice model by a statistically significant $(\mathrm{p}<0.05)$ margin of $47.62 \%$, while the standard loperamide produced $66.67 \%$ reduction of diarrheal feces. The central and peripheral analgesic activities of the crude methanol extract of $V$. farnesiana (MEVF) was determined by tail flick- and acetic acidinduced writhing methods, respectively, in Swiss albino mice. In the tail flick method, oral administration of MEVF at doses of 200 and $400 \mathrm{mg} / \mathrm{kg}$ body weight exhibited 221.09 and 237.09\% elongation of pain response time, respectively, after 90 minutes of administration whereas the standard morphine effectuated $518.34 \%$ elongation within the same time. Furthermore, the same doses of the extract illustrated 63.27 and $69.39 \%$ reductions, respectively, in the acetic acid-induced abdominal constrictions in mice. Compared to the standard acetylsalicylic acid with $75.51 \%$ inhibition, statistically significant $(\mathrm{p}<0.05)$ peripheral analgesic activity was established. The results of the present investigations suggest that methanol extract of $V$. farnesiana possesses antioxidant, antidiarrheal and analgesic activities which eventually indicates the presence of biologically important phytoconstituents within the plant that needs further exploration.
\end{abstract}

Key words: Vachellia farnesiana, antioxidant, antidiarrheal, central analgesic, peripheral analgesic.

\section{Introduction}

From antiquity, different geographically distinguished ethnomedicinal practices have contributed to the healthcare management of human societies. These intricate traditional systems formed and evolved around nature at their foundation, especially the plant kingdom (Newman et al., 2000). Detailed records have been recovered on the utilization of plants as part of many complementary medicinal systems including those of Chinese, Indian and Egyptian civilizations over different time periods
(Schultes and Raffauf, 1990). Originating in Indian subcontinent, the Ayurvedic system stands among the oldest of traditional medicinal practices. Earlier documents of this system have indicated Eugenia jambolana (black plum) in the treatment of diarrhea (Ravishankar and Shukla, 2007). On the contrary, practitioners of the Chinese traditional medicine have long been employing the rhizome of Zinziber officinale for alleviating diarrhea and other gastrointestinal discomforts (Cheng, 2000). Currently, global healthcare and pharmaceutical

Corresponding author: Mohammad A. Rashid; E-mail: r.pchem@yahoo.com

DOI: https://doi.org/10.3329/bpj.v23i1.48339 
management utilizes at least 119 plant-derived dug molecules which are predominantly provided by around 90 plant species. Nearly three-fourth of these compounds resulted from methodological phytochemical investigations into plants with prominent history of being employed as traditional medicine (Arvigo et al., 1993). This, in turn, provides a strong basis for biological assessment of different medicinal plants for potential bioactivities as well as bioactivity guided phytochemical researches that might lead to newer lead compounds in the future.

Vachellia farnesiana (L.) Wight \& Arn. along with its close relatives are indigenous to the tropical regions of America. The plant is generally represented by the name Acacia farnesiana and is commonly known as sweet acacia (The Plant List, 2013). On account of its fragrant flowers, the species experienced extensive circulation in many parts of the world, especially the tropical and subtropical regions and subsequently have become the most widely distributed among all Acacia species. Utilization of $V$. farnesiana plant have stemmed into diverse purposes. The rich content of essential oils within its flower have made it profoundly popular in the formulation of perfumes. Individual parts of the plant including leaves, barks, flowers and green pods are commonly employed by different traditional medicinal systems both in their native forms and as extract. In Mexico, the plant has long been known to be effective in the treatment of inflammation and diarrhea (Meckes et al., 2004). In India, branches of the plant are commonly used as toothbrush as it improves gum health. Similarly, the roots of the plant is also known to alleviate sore throat upon chewing. Both the bark and roots are astringent and demulcent in nature. Furthermore, the roots also employed traditionally as antispasmodic, anti-diarrheal, antirheumatic and stimulant (Biradar and Rachetti, 2013).

\section{Materials and Method}

Collection of plant material and extraction: Leaves and branches of $V$. farnesiana were collected from Mirpur, Dhaka, Bangladesh and identified in Bangladesh National Herbarium, Mirpur, Dhaka where a voucher specimen has been deposited. Following proper cleansing, the plant parts were air dried and ground to a coarse powder using a grinding machine. About $270 \mathrm{gm}$ of powdered sample was soaked in $1800 \mathrm{ml}$ of distilled methanol in a glass container for 15 days with occasional shaking and stirring to facilitate maximized extraction of phytoconstituents. The whole mixture was then filtered by cotton plug followed by Whatman (No. 1) filter paper. The filtrate was concentrated using a rotary evaporator at reduced temperature and low pressure. The concentrated gummy mass was transferred to a clean beaker. An aliquot (5 gm) of the concentrated extract of $V$. farnesiana was subjected to solvent-solvent partitioning following the modified Kupchan method (Van Wagenen et al., 1993) to yield $n$-hexane (HSF), dichloromethane (DCMSF), ethyl acetate (EASF) and aqueous soluble (AQSF) fractions. Then the crude extract and its Kupchan fractions were separately evaluated for biological activities.

Drugs and reagents: Acetic acid, methanol, Tween-80, Folin-Ciocalteu reagent and DPPH were purchased from the Merck Germany. Acetyl salicylic acid and Loperamide was collected from Beximco Pharmaceuticals Ltd., Bangladesh. Morphine was purchased from Gonoshasthaya Pharmaceuticals Ltd. whereas normal saline was procured from Opsonin Pharmaceuticals Ltd. Castor oil was purchased from local market. All the reagents were of analytical grade.

Experimental animal: Swiss-albino mice of either sex, aged 4-5 weeks, obtained from the Animal Resources Branch of the International Centre for Diarrheal Diseases and Research, Bangladesh (icddr,b) were used for the experiment. They were housed in standard polypropylene cages and kept under controlled room temperature $\left(24 \pm 2^{\circ} \mathrm{C}\right.$; relative humidity $60-70 \%$ ) in a 12 hours light-dark cycle and fed with icddr,b formulated rodent feed and water ad libitum. The animals were kept for four days in the laboratory environment prior to use for the experiments. The Federation of European Laboratory Animal Science Association's guidelines and 
recommendations were followed to reduce the pain and stress of the experimental mice. Twenty Swiss albino mice were randomly divided into four groups with five animals in each group for each in vivo test. The groups were named as positive control, negative control and two test groups receiving MEVF at doses of 200 and $400 \mathrm{mg} / \mathrm{kg}$ of body weight.

Total phenolic analysis: As developed and described by Skerget et al. (2005), the total phenolic content of the different samples viz. MEVF, HSF, DCMSF, EASF and AQSF were determined by employing Folin-Ciocalteu reagent as oxidizing agent and gallic acid as the standard for equivalence (Agbor et al., 2014).

Determination of antioxidant activity: DPPH (1,1diphenyl-2-picrylhydrazyl) free radical scavenging assay as developed by Brand-Williams et al. (1995) was followed for the determination of antioxidative potential of the extract.

Anti-diarrheal activity: Anti-diarrheal activity of the crude methanol extract of $V$. farnesiana was ascertained by following published method (Shoba and Thomas, 2001). The negative control group received $1 \%$ solution of tween-80 in normal saline at $10 \mathrm{ml} / \mathrm{kg}$ b.w. orally, while the positive control group received loperamide $(50 \mathrm{mg} / \mathrm{kg}$ b.w.) orally. The test groups were orally administered with extract of $V$. farnesiana at two different doses viz. 200 and 400 $\mathrm{mg} / \mathrm{kg}$ b.w. Then $1.0 \mathrm{ml}$ of castor oil was fed to each mouse to induce diarrhea after 30 minutes as time interval was necessary to ensure proper absorption of the administered substances. Each animal got an individual case, the floor of which was lined with blotting paper. Each of the mice was observed for 4 hours to record the number of stool giving instances. The average of total number of stools given by the test group, and the control group was compared and the percent inhibition of defecation in mice was calculated by using the following equation:

$$
\% \text { Inhibition }=(\mathrm{MC}-\mathrm{MT}) / \mathrm{MC} \times 100
$$

where, $\mathrm{MC}=$ mean defecation of control and MT $=$ mean defecation of test groups.

Determination of central analgesic activity: The central analgesic activity of $V$. farnesiana in mice was determined by the conventional tail flick method developed by Dewey et al. (1970). In this assay, two groups received the test samples (methanol extract of plant at 200 and $400 \mathrm{mg} / \mathrm{kg}$ b.w.) while the positive and negative control received standard drug morphine ( $2 \mathrm{mg} / \mathrm{kg}$ body weight, intraperitoneal) and normal saline, respectively. After 30 minutes of intervention, $1-2 \mathrm{~cm}$ of the tail of mice was submerged in warm water maintained around $55^{\circ} \mathrm{C}$. The response time, i.e., the time required by the mice to withdraw their tails from the hot water was measured. Unresponsiveness of 20 seconds was characterized as total absence of pain and the estimation was ceased to avoid damage to mice. The percent (\%) elongation of pain response was determined at $0,30,60$ and 90 minutes after administration of samples in mice.

Determination of peripheral analgesic activity: Peripheral analgesic activity of $V$. farnesiana extract was evaluated by acetic acid-induced writhing method (Saha and Ahmed, 2009). Here, the test samples and control drug were given orally to the mice at the beginning by means of a feeding needle. After 30 minutes, $1 \%$ acetic acid was administered via intra-peritoneal route to each mouse of all the groups to induce pain sensation. Between the oral administration of test materials and intraperitoneal administration of acetic acid, a time interval of 40 minutes was given to assure proper absorption of the administered samples. About 5 minutes after the administration of acetic acid, the number of squirms or writhing was counted for each mouse for 10 minutes.

\section{Result and Discussion}

The current study was undertaken to evaluate the antioxidant, antidiarrheal and analgesic activity of the extract of $V$. farnesiana.

The antioxidant activity of $V$. farnesiana was determined by using total phenolic content methods and free radical scavenging assay using DPPH. As shown in Table 1, the total phenolic content in MEVF and its various fractions varied from $0.67 \pm$ 0.09 to $39.26 \pm 0.85 \mathrm{mg}$ of gallic acid equivalent 
(GAE)/g of extractives. The EASF had the highest value of $39.26 \pm 0.85 \mathrm{mg}$ of GAE/gm of extractives, respectively followed by the AQSF $(12.52 \pm 1.01 \mathrm{mg}$ of GAE/gm of extractives) and MEVF (10.22 \pm 1.03 $\mathrm{mg}$ of GAE/gm of extractives).

A similar trend was observed in case of antioxidant activity assay. The EASF showed the highest antioxidant activity with $\mathrm{IC}_{50}$ vale of $21.49 \pm$ $1.04 \mu \mathrm{g} / \mathrm{ml}$ as compared to $20.41 \pm 0.05 \mu \mathrm{g} / \mathrm{ml}$ exhibited by the standard BHT. Previous studies have already established the presence of phenols, tannins in the plant which might be responsible for the observed antioxidant activities (Devi and Prasad, 1991).
The methanolic extract of $V$. farnesiana exhibited statistically significant $(\mathrm{p}<0.05)$ antidiarrheal activity with a $47.62 \%$ reduction of diarrhea at dose $400 \mathrm{mg} / \mathrm{kg}$ compared to the standard drug loperamide $66.67 \%$. However, $200 \mathrm{mg} / \mathrm{kg}$ dose of MEVF did not show statistically significant results with a reduction of only $19.05 \%$ (Table 2). The result suggested that the methanol extract of $V$. farnesiana possesses statistically significant anti-diarrheal activity only at higher doses. Further study, however, might be necessary to ascertain whether any dosedependent pattern is present in the response.

Table 1. Total phenolic content, antioxidant activity of $V$. farnesiana.

\begin{tabular}{lcc}
\hline Samples & $\begin{array}{c}\text { Total phenolic content } \\
(\mathrm{mg} \text { of GAE/g of extract) }\end{array}$ & $\begin{array}{c}\text { Antioxidant activity } \\
\mathrm{IC}_{50}(\mu \mathrm{g} / \mathrm{ml})\end{array}$ \\
\hline MEVF & $10.22 \pm 1.03$ & $126.4 \pm 3.44$ \\
HSF & $3.71 \pm 0.21$ & $84.63 \pm 2.27$ \\
DCMSF & $0.67 \pm 0.09$ & $212.48 \pm 3.21$ \\
EASF & $39.26 \pm 0.85$ & $21.49 \pm 1.04$ \\
AQSF & $12.52 \pm 1.01$ & $83.04 \pm 1.32$ \\
BHT & - & $20.41 \pm 0.05$ \\
\hline
\end{tabular}

All the values are expressed as Mean \pm SEM.

Table 2. Antidiarrheal activity of methanol extract of $V$. farnesiana in Swiss Albino mice.

\begin{tabular}{lccc}
\hline Test groups & $\begin{array}{c}\text { Dose } \\
(\mathrm{mg} / \mathrm{kg} \text { of body weight })\end{array}$ & $\begin{array}{c}\text { Number of diarrheal feces } \\
(\text { Mean } \pm \text { SEM })\end{array}$ & $\begin{array}{c}\text { Inhibition of diarrhea } \\
(\%)\end{array}$ \\
\hline $\begin{array}{l}\text { Negative Control } \\
\text { (Normal saline) }\end{array}$ & $10 \mathrm{ml}$ & 7.00 & - \\
\hline $\begin{array}{l}\text { Positive control } \\
\text { (Loperamide) }\end{array}$ & 50 & 2.33 & $66.67 *$ \\
\hline $\begin{array}{l}\text { Methanol extract of } V . \\
\text { farnesiana }\end{array}$ & 200 & 5.67 & 19.05 \\
\hline
\end{tabular}

All values are expressed as mean $\pm \operatorname{SEM}(n=3), *$ indicates statistical significance of $p<0.05$.

During central analgesic activity assay, the MEVF exhibited dose-dependent pain reducing activity in experimental mice. The plant extract at 200 and $400 \mathrm{mg} / \mathrm{kg}$ body weight, significantly (p < 0.05 ) inhibited the pain response by $101.73 \%$ and $141.25 \%$ at 90 minutes of intervention, respectively which were close to that of standard drug morphine (276.56\%). In this experiment, the highest elongation of pain response $(237.09 \%)$ was observed by the plant extract at $400 \mathrm{mg} / \mathrm{kg}$ b.w. at 90 minutes whereas morphine showed a maximum elongation by $518.34 \%$ (Table 3). 
The pain reducing effects of $V$. farnesiana against acetic acid-induced writhing in mice have been illustrated in Table 4. The tested plant extract, MEVF (200 and $400 \mathrm{mg} / \mathrm{kg}$ body weight) and the standard acetyl salicylic acid $(50 \mathrm{mg} / \mathrm{kg}$ body weight $)$ significantly $(\mathrm{p}<0.05)$ reduced abdominal contractions in mice. The MEVF at 200 and 400 $\mathrm{mg} / \mathrm{kg}$ body weight inhibited the writhing response by $63.27 \%$ and $69.39 \%$, respectively as compared to $75.51 \%$ exhibited by acetylsalicylic acid.

Table 3. Central analgesic activity of methanol extract of $V$. farnesiana.

\begin{tabular}{|c|c|c|c|c|c|c|c|}
\hline \multirow[t]{2}{*}{ Test groups } & \multirow[t]{2}{*}{$\begin{array}{c}\text { Dose } \\
(\mathrm{mg} / \mathrm{kg})\end{array}$} & \multicolumn{3}{|c|}{$\begin{array}{l}\text { Time of tail immersion } \\
\quad(\text { Mean } \pm \text { SEM })\end{array}$} & \multicolumn{3}{|c|}{$\begin{array}{l}\text { Elongation of pain inhibition } \\
\qquad(\%)\end{array}$} \\
\hline & & $30 \mathrm{~min}$ & $60 \mathrm{~min}$ & $90 \mathrm{~min}$ & $30 \mathrm{~min}$ & $60 \mathrm{~min}$ & $90 \mathrm{~min}$ \\
\hline Negative control & $10 \mathrm{ml}$ & $1.80 \pm 0.08$ & $2.51 \pm 0.15$ & $2.21 \pm 0.19$ & - & - & - \\
\hline $\begin{array}{l}\text { Positive control } \\
\text { (Morphine) }\end{array}$ & 2 & $5.38 \pm 0.43$ & $9.44 \pm 0.23$ & $13.67 \pm 0.16$ & 185.60 & 276.56 & 518.34 \\
\hline MEVF & 200 & $3.94 \pm 0.28$ & $6.05 \pm 0.27$ & $7.45 \pm 0.19$ & 109.09 & 101.73 & 221.09 \\
\hline MEVF & 400 & $4.21 \pm 0.09$ & $5.06 \pm 0.17$ & $8.3 \pm 0.39$ & 123.85 & 141.25 & 237.09 \\
\hline
\end{tabular}

All values are expressed as mean \pm SEM $(n=3)$, all responses were found to be statistically significant $(p<0.05)$.

Table 4. Peripheral analgesic activity of methanol extract of $V$. farnesiana.

\begin{tabular}{lcccc}
\hline Test groups & $\begin{array}{c}\text { Dose } \\
(\mathrm{mg} / \mathrm{kg} \text { of body } \\
\text { weight })\end{array}$ & $\begin{array}{c}\text { Average number of } \\
\text { writhing } \\
(\text { Mean } \pm \mathrm{SEM})\end{array}$ & $\begin{array}{c}\text { Writhing/ pain } \\
\text { response } \\
(\%)\end{array}$ & $\begin{array}{c}\text { Inhibition of pain } \\
\text { response } \\
(\%)\end{array}$ \\
\hline $\begin{array}{l}\text { Negative Control } \\
\text { (Normal saline) }\end{array}$ & $10 \mathrm{ml}$ & $16.33 \pm 0.09$ & 100 & - \\
\hline $\begin{array}{l}\text { Positive control } \\
\text { (Acetylsalicylic acid) }\end{array}$ & 50 & $4.00 \pm 0.67$ & 24.49 & 75.51 \\
\hline $\begin{array}{l}\text { Methanol extract of } V . \\
\text { farnesiana }\end{array}$ & 200 & $6.00 \pm 1.20$ & 36.73 & 63.27 \\
\hline
\end{tabular}

All values are expressed as mean $\pm \operatorname{SEM}(n=3)$, all responses were found to be statistically significant $(\mathrm{p}<0.05)$.

Both the tail immersion test and the writhing method are very useful techniques for the evaluation of central and peripheral analgesic activity of plant extracts, respectively (Amir and Shikha, 2004; Adeyemi et al., 2004). The central analgesic action is generally effectuated through the inhibition of central pain receptors within the brain and spinal cord (Sharma et al., 2003; Khanna and Bhatia, 2003). Opiates such as morphine exert central analgesia by interacting with specific class of central pain receptors named opioid receptors (Wani et al., 2012). In our experiment, standard morphine caused significant analgesic effect in mice and the effect became more prominent as time increased. Similar dose-dependent effects were observed in case of the plant extract. The peripheral analgesic activity is commonly intervened either through inhibition of cyclooxygenase pathway or through direct suppression of nociceptors (Amir and Shikha, 2004; Duarte et al., 1988). In this study, V. farnesiana extract showed dose-dependent inhibition of pain in mice model secondary to both central and peripheral inhibitory mechanisms. Further phytochemical investigations are required to isolate the bioactive components responsible for these activities.

\section{Conclusion}

The results of the present study provide reasonable indication that the ethyl acetate soluble fractions of $V$. farnesiana possess significant antioxidant property whereas the methanol extract is capable of exerting prominent antidiarrheal and analgesic properties. However, extensive studies are 
needed to isolate the bioactive compounds from this plant extracts which are responsible for aforementioned pharmacological activities.

\section{References}

Adeyemi, O.O., Okpo, S.O. and Okpaka, O. 2004. The analgesic effect of the methanolic extract of Acanthus montanus. J. Ethnopharmacol. 90, 45-48.

Agbor, G.A., Vinson, J.A. and Donnelly, P.E. 2014. FolinCiocalteau reagent for polyphenolic assay. Int. J. Food Sci. Nutr. Diet. 3, 147-156.

Amir, M. and Shikha, K. 2004. Synthesis and antiinflammatory, analgesic, ulcerogenic and lipid peroxidation activities of some new $2-[(2,6-$ dichloroanilino) phenyl] acetic acid derivatives. Eur. J. Med. Chem. 39, 535-545.

Arvigo, R., Balick, M.J. and Evans, L. 1993. Rainforest Remedies: One Hundred Healing Herbs of Belize. Lotus Press, Wisconsin.

Biradar, S.R. and Rachetti, B.D. 2013. Extraction of some secondary metabolites \& thin layer chromatography from different parts of Acacia farnesiana L. IOSR J. Pharm. Biol. Sci. 7, 44-48.

Brand-Williams, W., Cuvelier, M.E. and Berset, C.L.W.T. 1995. Use of a free radical method to evaluate antioxidant activity. LWT-FOOD Sci. Technol. 28, 2530.

Cheng, J.T. 2000. Drug therapy in Chinese traditional medicine. J. Clin. Pharmacol. 40, 445-450.

Devi, S.R. and Prasad, M.N.V. 1991. Tannins and related polyphenols from ten common Acacia species of India. Bioresour. Technol. 36, 189-192.

Dewey, W.L., Harris, L.S., Howes, J.F. and Nuite, J.A. 1970. The effect of various neurohumoral modulators on the activity of morphine and the narcotic antagonists in the tail-flick and phenylquinone tests. $J$. Pharmacol. Exp. Ther. 175, 435-442.

Duarte, I.D., Nakamura, M. and Ferreira, S.H. 1988. Participation of the sympathetic system in acetic acid induced writhing in mice. Braz. J. Med. Biol. Res. 21, 341-343.
Khanna, N. and Bhatia, J. 2003. Antinociceptive action of Ocimum sanctum (Tulsi) in mice: possible mechanisms involved. J. Ethnopharmacol. 88, 293- 296.

Meckes, M., David-Rivera, A.D., Nava-Aguilar, V. and Jimenez, A. 2004. Activity of some Mexican medicinal plant extracts on carrageenan-induced rat paw edema. Phytomedicine. 11, 446-451.

Newman, D.J., Cragg, G.M. and Snader, K.M. 2000. The influence of natural products upon drug discovery. Nat. Prod. Rep. 17, 215-234.

Ravishankar, B. and Shukla, V.J. 2007. Indian systems of medicine: a brief profile. Afr. J. Tradit. Complement. Altern. Med. 4(3), pp.319-337.

Saha, A. and Ahmed, M. 2009. The analgesic and antiinflammatory activities of the extract of Albizia lebbeck in animal model. Pak. J. Pharm. Sci. 22, 74-77.

Schultes, R.E. and Raffauf, R.F. 1990. The Healing Forest: Medicinal and Toxic Plants of the northwest Amazonia. Dioscorides Press, Oregon, p. 484.

Sharma, S., Jain, N.K. and Kulkarni, S.K. 2003. Inhibition of COX-1 enzyme potentiate opioid-induced antinociception in animal model of central nociception. Indian J. Pharmacol. 35, 21-26.

Skerget, M., Kotnik, P., Hadolin, M., Hras, A.R., Simonic, M. and Knez, Z. 2005. Phenols, proanthocyanidins, flavones and flavonols in some plant materials and their antioxidant activities. Food Chem. 89, 191-198.

The Plant List. 2013. Version 1.1. Published on the Internet; http://www.theplantlist.org/ (last accessed $16^{\text {th }}$ June, 2020).

VanWagenen, B.C., Larsen, R., Cardellina, J.H., Randazzo, D., Lidert, Z.C. and Swithenbank, C. 1993. Ulosantoin, a potent insecticide from the sponge Ulosa ruetzleri. J. Org. Chem. 58(2), 335-337.

Wani, T.A., Kumar, D., Prasad, R., Verma, P.K., Sardar, K.K., Tandan, S.K. and Kumar, D., 2012. Analgesic activity of the ethanolic extract of Shorea robusta resin in experimental animals. Indian J. Pharmacol. 44, 493-499. 